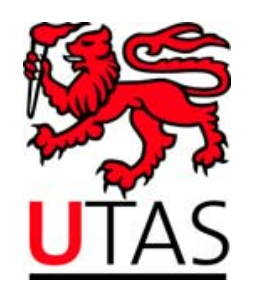

SCHOOL OF ECONOMICS AND FINANCE

Discussion Paper 2012-11

Crude Oil Prices and Liquidity, the BRIC and G3 countries

Ronald A Ratti and Joaquin L Vespignani

ISSN 1443-8593

ISBN 978-1-86295-685-8 


\title{
Crude Oil Prices and Liquidity, the BRIC and G3 countries $^{\Delta}$
}

\author{
Ronald A. Ratti ${ }^{\mathrm{a}^{*}}$ and Joaquin L. Vespignani ${ }^{\mathrm{b}^{* *}}$ \\ ${ }^{a}$ University of Western Sydney, School of Business, Australia \\ ${ }^{\mathrm{b}}$ University of Tasmania, School of Economics and Finance, Australia
}

\begin{abstract}
Unanticipated increases in the BRIC countries' liquidity lead to significant and persistent increases in real oil prices, global oil production and global real aggregate demand. Unanticipated shocks to the liquidity of developed countries over 1997:01-2011:12 do not. The relative contribution to real oil price of liquidity in BRIC countries to liquidity in developed countries is much greater since 2005 than before 2005. China and India drive the results for the effect of BRIC countries' liquidity on real oil price and global oil production. China and India and Brazil and Russia reinforce one another on the effect of liquidity on global real aggregate demand. Due to the difference between countries as commodity importers/exporters, the liquidity of Brazil and Russia increases significantly with a rise in real oil price and that of China and India decreases significantly with a rise in real oil price. It is shown that the strong rebound in oil price during 2009 is mostly due to strong effects of shocks to liquidity in the BRIC countries. The analysis helps in assessing the importance of the BRIC economies in the upsurge of the real price of crude oil.
\end{abstract}

Keywords: Oil Price, BRIC countries, China and India, Global liquidity

JEL Codes: E31, E32, E51, F01, G15, Q43

\footnotetext{
** Corresponding author: Joaquin L. Vespignani; University of Tasmania, School of Economics and Finance, Australia; Tel. No: +61 3 62262825; E-mail address: Joaquin.Vespignani@utas.edu.au

*Ronald A. Ratti; University of Western Sydney, School of Business, Australia; Tel. No: +61 2 9685 9346; E-mail address: $\underline{\text { r.ratti@uws.edu.au }}$
}

\footnotetext{
${ }^{\Delta}$ The authors thank Lutz Kilian and Mardi Dungey for helpful suggestions on improving this work.
} 


\section{Crude Oil Prices and Liquidity, the BRIC and G3 countries}

\section{Introduction}

A number of papers in the literature have emphasized the effect of global liquidity on the prices of broader categories of assets and on the prices of goods. Darius and Radde (2010) argue that the current interest in global liquidity is tied to the possible implications for the determination of asset prices and to the view that the effectiveness of domestic monetary policy is debilitated due to external global factors. Belke, Orth and Setzer (2010) document that global liquidity has risen since 2001 with impacts on the price of assets in inelastic supply such as housing and commodities. ${ }^{1}$ Brana, Djigbenou, and Prat (2012) link global excess liquidity to asset prices in emerging economies. Belke, Bordon and Hendricks (2010) find that causality between monetary aggregates and oil prices runs both ways. Barsky and Kilian (2002) connect large increases in global liquidity measured by money growth in the United States and nine other OECD countries with the substantial increase in commodity prices preceding the increase in oil prices in 1973-1974. Baks and Kramer (1999), Ruffer and Stracca (2006) and Sousa and Zaghini (2007) find that global excess liquidity signals inflationary pressure at a global level. D'Agostino and Surico (2009) demonstrate that global liquidity has predictive power for the U.S. inflation rate.

In parallel with these analyses Hamilton (2009; 2011) and Kilian and Hicks (2012) associate the rise in real oil price over 2003-2008 with growth in emerging economies, primarily that in China and India. In this paper we seek to determine the influence of liquidity as it arises from the major developed and major developing economies on the price of crude oil. Our view is that increases in liquidity increase oil prices and that it matters where the innovation in liquidity is originating. The major developing economies are taken to be the BRIC countries comprised of Brazil, the Russian Federation, India and China. The BRIC countries have not only had dramatic increases in real

\footnotetext{
${ }^{1}$ Adalid and Detken, (2007) and Greiber (2007) find that liquidity spill-overs impact real house prices. Darius and Radde (2010) show that global liquidity has impacts on house prices and a commodity price index (but not equity prices and oil prices). Gerdesmeier, Roffia and Reimers (2009) find that high money and credit growth are associated with an asset price boom some quarters later.
} 
income, but also considerable increases in liquidity in recent years. A structural vector error correction model is employed in the analysis.

Unanticipated increases in the BRIC countries' liquidity lead to significant and persistent increases in real oil prices, global oil production and global real aggregate demand. The responses of global oil production, global real aggregate demand and real oil prices to an unanticipated shock to the liquidity of developed countries are not as large and are not statistically significant. The relative contribution to real oil price of liquidity in BRIC countries compared to that of liquidity in developed countries is much greater since 2005 than before 2005. The relative contribution of the BRIC countries' liquidity to real oil price is particularly marked during 2007 and 2010. Oil price fell sharply at the end of 2008 and then rose strongly over 2009-2010 when the global economy was weak. It is shown that this strong rebound in oil price during 2009 is mostly due to strong effects of shocks to liquidity in the BRIC countries.

It is found that China and India (major commodity importing countries) drive the results for the effect of BRIC countries' liquidity on real oil price and global oil production. China and India and Brazil and Russia reinforce one another on the effect of liquidity on global real aggregate demand. Due to the difference between the two groups of emerging countries in terms of their differences as commodity importers/exporters, the liquidity of Brazil and Russia (major commodity exporting countries) increases significantly with a rise in real oil price whereas that of China and India decreases significantly with a rise in real oil price. The analysis helps understand the causes of movement in oil prices over the last twenty years and assists in assessing the importance of the BRIC economies in the upsurge of the real price of crude oil.

The behaviour of the BRIC countries' liquidity and that of other major countries is examined in Section 2. The structural vector error correction (SVEC) model for analysis of liquidity and real crude oil prices is discussed in Section 3. The empirical results are presented in Section 4. The 
question of whether China and India drive the results is examined in Section 5 and tests of robustness of results are conducted in Section 6. Section 7 concludes.

\section{The BRIC and G3 countries' Liquidity}

In this study we will use real M2 as a measure of liquidity for the BRIC (Brazil, Russia, India and China) and G3 (Eurozone, Japan and U.S.) countries. This is determined by the availability of monthly M2 data for the countries involved over 1997:1 to 2011:12. ${ }^{2}$ The BRIC countries have become much more important providers of global liquidity in recent years. Information on M2 in U.S. dollars for the BRIC countries and for the G3 over 1997:01-2011:12 is provided in Figure 1. Figure 1a presents the nominal money supplies of Brazil, Russia, India and China and Figure $1 \mathrm{~b}$ presents the nominal money supplies for the Eurozone, Japan and the U.S. The scale of the left hand side of Figure 1a is for M2 for Brazil, Russia and India, and the scale of the right hand side of Figure 1a is for M2 for China. Over the fifteen years from 1997:01 to 2011:12 M2 is up approximately by factors of 4.8, 15.5, 7.5 and 14.2 in Brazil, Russia, India and China, respectively. Overall, M2 for the BRICs is up by a factor of 13.3. In contrast, over 1997:01 to 2011:12, M2 is up by factors of 2.6, 2.2 and 2.5 in the Eurozone, Japan and the U.S., respectively, and M2 is up by a factor of 2.4 in the G3.

The rise of BRIC countries money supply as share of global money supply has been marked. If Global M2 is taken to be the sum of the M2 in the BRICs and in the G3, in Figure 1c the BRICs share of global M2 has increased from 8.4\% in 1997:01 to 33.3\% in 2011:12. The rate of increase in

\footnotetext{
${ }^{2}$ A variety of measures of global liquidity have been employed in the literature. Sousa and Zaghini (2007) construct a quarterly (G5) global liquidity indicator based on aggregating broad money indicators for the U.S. (M2), Japan (M2+), the United Kingdom (M4), the Eurozone (M3) and Canada (M2+). The monetary aggregate used for each country is indicated in parenthesis. Belke et al. (2010) build a quarterly global liquidity indicator built on monetary aggregates for the U.S., the Eurozone, Japan, United Kingdom, Canada, South Korea, Australia, Switzerland, Sweden, Norway and Denmark. The monetary aggregate is M2 for the US, M3 for the Eurozone, M2 plus cash deposits for Japan, M4 for the UK and mostly M3 for the other countries. For a measure of global liquidity based on narrower monetary aggregates Brana et al. (2012) construct a monthly global monetary base founded on the U.S., United Kingdom, Japan, Australia, New Zealand, Sweden, Denmark, the Eurozone, China, South Africa, ten countries from Central and Eastern Europe including Russia, and Qatar, Kuwait and Saudi Arabia. Darius and Radde (2010) construct a quarterly measure of global liquidity given by the sum of the U.S. monetary base and world international reserves. Ruffer and Stracca (2006) and Brana et al. (2012) provide a review and discussion of alternative measures of global liquidity.
} 
M2 in the BRIC countries has also been relatively large when scaled by nominal GDP (showing an unprecedented upward trend after 2008). This is illustrated in Figure 1d. Over 1997-2011 the M2/GDP ratio for the G3 increased by $36 \%$ and for the BRICs has increased by $137 \%$. The monetary aggregate/nominal GDP ratio has been adopted as an excess liquidity in a number of studies.

The real oil price in U.S. dollars based on an index of 100 in 1997:01 is shown in Figure 1e. The index for real oil price stands at about 398 in 2011:12, having peaked at 531 in 2008:06. An index for the sum of real M2 in U.S. dollars in China and India is also shown in Figure 1e. The deflator is the U.S. CPI. In this paper we investigate whether liquidity in China and India and in the BRIC countries has played a role in influencing the real price of oil.

\section{The model}

Hamilton's (1983) influential paper on the effect of oil prices on the U.S. economy treated oil prices changes as exogenous over the post-World War II period. This assumption was retained in work by Kim and Loungani (1992), Lee, Ni and Ratti (1995), and Bernanke, Gertler and Watson (1997), among many others. Leduc and Sill (2007), Bodenstein, Erceg and Guerrieri (2008) and Gillman and Nakov (2009) relax this belief and treat oil price as endogenous and oil as either fixed in supply or with supply growing at an exogenously given rate. The endogeneity of global oil production and oil production decisions is now receiving greater attention in the literature. Elekdag et al. (2008) model oil producers as operating under monopolistic competition and Nakov and Pescatori (2010) model productions decision in the oil sector in which there is a dominant producer. Bodenstein, Guerrieri and Kilian (2012) develop a DSGE model and analyse interdependency between monetary policy and supply and demand for oil in global markets. A major contribution by Kilian (2009) is the decomposition of the structural shocks influencing the movement of real oil price and an examination of how these structural shocks evolve over time. 
In this paper the real price of oil and oil production are treated as endogenous. In our model we examine the contributions to real oil price from global oil supply, global real aggregate demand, specific oil-demand, aggregated real M2 for G3 countries, and aggregated real M2 for BRIC countries shocks. A structural vector error correction model will be employed in the analysis. The shocks that cannot be explained by oil supply, global real aggregate demand and monetary aggregate shocks will reflect the oil-specific or precautionary shocks due to worries about future oil supplies. ${ }^{3}$

\subsection{Data and variables}

The sample period is from 1997:1 to 2011:12. The starting date is dictated by the availability of monthly M2 data for the Russian Federation and for China. The variable $G O_{t}$ is the global oil production in millions of barrels average pumped per month from U.S. Department of Energy. Global real aggregate demand $A D_{t}$ is the global industrial production index reported by International Financial Statistics (IMF). ${ }^{4}$ Real oil price $R P_{t}$ is the spot price of Western Texas Intermediate (WTI) oil from the U.S. Department of Energy divided by the U.S. consumer price index $(\mathrm{CPI}){ }^{5}$

$G 3 M 2_{t}$ is constructed by aggregating M2 in U.S. dollars for the three largest economies, the United States (U.S.), the Eurozone and Japan divided by the U.S. CPI. Finally, BRICM2 $2_{t}$ is the aggregation of M2 in U.S. dollars for the developing economies; Brazil, Russian Federation, India and China divided by the U.S. CPI. The M2 data for U.S., Eurozone, Japan, Brazil and Russian Federation is from International Monetary Fund and the Federal Reserve Bank of St. Louis, while Chinese and Indian M2 are from People's Bank of China and Reserve Bank of India, respectively. ${ }^{6}$

\footnotetext{
${ }^{3}$ These shocks are the residual of real oil price equation in Kilian (2009).

${ }^{4}$ Advantages of global industrial production reported by the IMF are that it is available at a monthly frequency in contrast to real GDP which is only available quarterly.

${ }^{5}$ In the literature on oil price shocks most of the analysis is in terms of real oil price effects. The deflator is usually the U.S. CPI.

${ }^{6}$ Note for India the monetary aggregates L2 has been used as a proxy of M2, as the Reserve Bank of India does not report monthly M2 aggregates for this period.
} 
The exchange rate data to convert M2 series from domestic currency into U.S. dollars was obtained from Federal Reserve Bank of St. Louis. ${ }^{7}$

\subsection{Unit root and co-integration}

Engle and Granger (1987) point out that a linear combination of two or more nonstationary series may be stationary. The stationary combination may be interpreted as the cointegration. When variables are cointegrated is standard in the literature to specify the model using a structural vector error correction model (VEC) rather than a vector autoregressive model (VAR).

To verify the order of integration in our data we test for unit root process, the Augmented Dickey Fuller (ADF), Dickey Fuller GLS (DF-GLS) and the Phillip-Perron (PP) unit root tests reveal that the logs of $G O_{t}, A D_{t}, R P_{t}, G 3 M 2_{t}, B R I C M 2_{t}$ are only first difference stationary or integrated of order one $I(1) .^{8}$ The null hypothesis of unit root cannot be rejected even at $20 \%$ level for those series in levels but can be rejected at $1 \%$ level of significant when these series are differentiated. Results are confirmed by the Kwiatkowski-Phillips-Schmidt-Shin (KPSS) test where the inverse null hypothesis is tested. These test results are reported in Table 1.

To formally establish the cointegration relationship among these five variables, we use the Johansen's cointegration test. ${ }^{9}$ We include the $\log s$ of the five $I(1)$ variables in a VAR model using the variable order described in equation 4 and the lag structure determined by the Schwarz Bayesian Criterion (SBC). The standard VAR Johansen trace and eight values test consistently support the hypothesis of one cointegration vector among the five variables in both cases, when no intercept or trend are included in the error correction term (ECT) and when intercept or trend is included in the VAR system as reported in Table 2 .

\subsection{Methodology}

\footnotetext{
${ }^{7}$ Russian federation exchange rate has been interpolated from the annual series as monthly data for Ruble /U.S. dollars is not available for the full sample period.

${ }^{8}$ Note that for the variable $\log \left(B R I C M 2_{t}\right)$ only the ADF and PP test indicate this variable is $I(1)$ in table $1 \mathrm{a}$. Further tests (e.g. Elliot-Rothenberg-Stock (ERS) and Ng-Perron (NP)) and optical inspection also support the hypothesis of $\log \left(B R I C M 2_{t}\right)$ being $I(1)$

${ }^{9}$ For more detail of this test please see Enders (2004), pp. 362.
} 
To identify changes in real oil price arising from oil supply shocks, global real aggregate demand shocks, oil sector specific-demand shocks, and shocks to real M2 for G3 countries and real M2 for BRIC countries we employ a structural VEC model (SVEC) model capturing the cointegration among all variables in the system. The SVEC model is expressed in matrix form as (for simplicity the constant term is omitted):

$$
B_{0} X_{t}=\beta+\sum_{i=1}^{j} B_{i} X_{t-i}+\rho E C T_{t-1}+\varepsilon_{t}
$$

where $j$ is the optimal lag length, determined by the SBC (two lags in this case), $X_{t}$ is vector of endogenous variables, $E C T_{t}$ is the error correction term, and $\varepsilon_{t}$ is the vector of structural changes, which is serially and mutually independent.

The endogenous variables in the model are:

$$
X_{t}=\left[\Delta \log \left(G O_{t}\right), \Delta \log \left(A D_{t}\right), \Delta \log \left(R P_{t}\right), \Delta \log \left(G 3 M 2_{t}\right), \Delta \log \left(B R I C M 2_{t}\right)\right]
$$

And the error correction term $\left(E C T_{t}\right)$ :

$$
E C T_{t}=\log \left(G O_{t}\right)-\beta-\psi \log \left(A D_{t}\right)-\gamma \log \left(R P_{t}\right)-\delta \log \left(G 3 M 2_{t}\right)-\alpha \log \left(B R I C M 2_{t}\right)
$$

Consistent with our cointegration tests in Table 2 and restrictions imposed in equation 4 (Cholesky lower triangle matrix), the $E C T_{t}$ is specified by normalizing the less endogenous variable in the system $\left(\log \left(G O_{t}\right)\right)$ and specifying a constant term but no trend.

To identify the model restriction are imposed in the $B_{O} X_{t}$ vectors as follows:

$$
B_{o} X_{t}=\left[\begin{array}{ccccc}
1 & 0 & 0 & 0 & 0 \\
-b_{20} & 1 & 0 & 0 & 0 \\
-b_{30} & -b_{31} & 1 & 0 & 0 \\
-b_{40} & -b_{41} & -b_{42} & 1 & 0 \\
-b_{50} & -b_{51} & -b_{52} & -b_{53} & 1
\end{array}\right]\left[\begin{array}{c}
\Delta \log \left(G O_{t, 10}\right) \\
\Delta \log \left(A D_{t, 20}\right) \\
\Delta \log \left(R P_{t, 30}\right) \\
\Delta \log \left(G 3 M 2_{t, 40}\right) \\
\Delta \log \left(B R I C M 2_{t, 50}\right)
\end{array}\right]
$$

Model restrictions are similar to those in Killian (2009), to the extent possible, given the inclusion in our model of the monetary variables and estimation of a SVEC model. ${ }^{10}$ Restrictions are

\footnotetext{
${ }^{10}$ Kilian's (2009) model is a structural VAR and not a SVEC.
} 
only imposed in the contemporaneous matrix. These restrictions are placed using Cholesky lower triangle matrix shown in equation (4). The restrictions in equation (4) imply that shocks to oil production are assumed to not respond to the other structural shocks contemporaneously, since oil production is unlikely to respond to the other shocks within the same month. Global real aggregate demand is assumed to respond contemporaneously to, for example, an oil production shortage, but not to monetary variables and oil prices. Innovations to the real price of oil not explained by shocks to oil supply or global real aggregate demand will reflect changes in the sector specific demand for oil. The system (4) implies that shocks to global oil production, global real aggregate demand, and real oil price will influence contemporaneously by real M2 in the G3 and in the BRIC countries, and not the reverse. The placing of monetary variables after that of real oil price is consistent with Kilian and Lewis (2011). ${ }^{11}$ It is assumed that the BRIC countries' M2 depends contemporaneously on the G3 M2 due to smaller aggregate size.

\section{The empirical results}

\subsection{VEC model results}

In table 3, the five equations system results for the VEC model are presented. Contemporaneous BRICM2 is statistically significant explaining oil production and with lags statistically significant explaining real aggregate demand and real oil prices. However, the G3M2 is not statistically significant explaining neither oil production, real aggregate demand or real oil prices. The error correction coefficient is statistically significant at $1 \%$ for the oil production equation and statically significant at $12 \%$ for both real oil prices and BRICM2. This confirms that when there is a deviation from the cointegration relationships as measure by the ECT, mainly changes in oil production, real oil prices and BRICM2 adjust in the return to the long term equilibrium.

\footnotetext{
${ }^{11}$ Kilian and Lewis (2011) includes the Federal fund rate in a structural VAR model immediately after the real oil price in an analysis of the relationship between monetary policy and real oil prices.
} 


\subsection{Impulse response function results}

Figure 2 shows the responses of the variables in the SVEC to one-standard deviation structural innovations. The dashed lines represent a two standard error confidence band around the estimates of the coefficients of the impulse response functions. ${ }^{12}$ In the first column are shown the responses of global oil production, global real aggregate demand, real price of oil, G3 real M2 and BRIC real M2 to a structural (positive) innovation in global oil production. The effect of an unanticipated supply disruption on global oil production is very persistent and highly significant. An unanticipated negative innovation in global oil production does not cause significant effects on the real price of oil or on global real aggregate demand. A disruption to global oil production causes an insignificant decline in BRIC country M2, and a decline in G3 M2 that is significant in the first month.

In the second column of Figure 2 a positive global real aggregate demand shock has a persistent positive effect on global oil production that is not statistically significant. An unanticipated global real aggregate demand expansion has a very persistent and highly significant effect on global real aggregate demand that rises over time. A positive global real activity shock has a positive and persistent effect on real oil prices that is statistically significant for about five months. ${ }^{13}$ A positive shock to global real activity causes G3 real M2 to increase, significantly in the first month, and then gradually erode. A positive shock to global real activity causes BRIC real M2 to fall, but the effect is not statistically significant.

The effects of an oil market-specific demand shock are shown in column 3 of Figure 2. In the third row of column 3 a positive shock in oil market-specific demand shock has a large and persistent

\footnotetext{
${ }^{12}$ The confidence bands are obtained using Monte Carlo integration as described by Sims (1980), where 5000 draws were used from the asymptotic distribution of the VAR coefficient.

${ }^{13}$ This result is different from the finding by Kilian (2009) for 1973:1-2007:12 in that a positive shock to global real aggregate demand for all industrial commodities resulted in a significant oil price increase that builds up over the first year and then is sustained at a large value. The difference in findings here is due to the different sample periods rather than use of Kilian's (2009) SVAR and measurement of aggregate demand by demand for all industrial commodities or the inclusion of M2 variables in the SVAR. For a 3 variable SVAR along the lines of Kilian's (2009) model estimated over 1996:1-2011:12, results are that a positive shock to aggregate demand for all industrial commodities causes a significant effect on real oil price only over the first three months (after which the effect gradually erodes).
} 
positive effect on the real price of oil. This effect is highly statistically significant and rises in magnitude over the first three months. An oil market-specific demand shock is not associated with significant effects on global oil production, but is linked with significant increases in global real aggregate demand. A positive oil market-specific demand shock is associated with insignificant declines in G3 real M2 and increases in BRIC real M2.

In the fourth and fifth columns are shown the responses of the variables to structural innovations in G3 M2 and BRIC M2, respectively. In response to an unanticipated increase in the BRIC countries' real M2 there are significant and persistent increases in global oil production, global real aggregate demand and in real oil prices. After the shock to BRIC real M2, the increase in global oil production builds up and is statistically significant after the fifth month and remains so for the remaining fifteen months shown. The rise in global real aggregate demand is statistically significant over all twenty months. The increase in real oil prices is statistically significant for sixteen months. The responses of global oil production, global real aggregate demand and real oil prices to an unanticipated shock to G3 real M2 are not statistically significant and are much smaller than the responses to shocks to BRIC M2.

These results underline the fact that for effects on real oil prices it matters where the innovation in money is originating. Over 1997:01-2011:12 an innovation in BRIC countries' real M2 has significant effects on oil production, on global aggregate demand and on real oil price, whereas an innovation in real M2 in the G3 does not. A further asymmetry between the roles of BRIC real money and G3 real money lies in the effects that they have on each other. In the fourth column and last row of Figure 2, an unanticipated increase in the G3 real M2 significantly increases BRIC countries' real M2. The effect is substantial within two months, persists and remains statistically significant even after twenty months. An unanticipated increase in the BRIC countries' real M2, on the other hand, does not significantly affect G3 real M2.

\subsection{Historical decomposition of real oil price}


The cumulative contribution to the real price of oil of the structural shocks to global oil production, global real aggregate demand, oil-specific demand, G3 real M2 and BRIC real M2 are reported in Figure 3 from estimating the SVEC model in equation (4). For background it should be noted that in the monthly data, spot prices per barrel for WTI are \$58.14 in January 2007 and \$140 in June 2008. Spot price for WTI is \$41.68 in January 2009 and is \$133.93 in April 2011.

The behaviour of the contributions of global demand, G3 and BRIC real M2 to real oil price during the early part of the period in Figure 3 reflects the recovery from Asian financial crisis with world petroleum consumption returning to strong growth in 1999 and then the onset of recession in the U.S. beginning in March of 2001. On the production side, the cumulative contribution of shocks to global oil production to real oil price over 2002 is related to a number of factors. In 2003 there was political unrest in Venezuelan and the second Persian Gulf War. Hamilton (2011) notes that further contributing factors to stagnation of oil production over 2002-2008 includes instability in places like Iraq and Nigeria, a fall in production from the North Sea and from fields in Mexico and Indonesia, and that Saudi production was lower in 2007 than in $2005 .{ }^{14}$

In Figure 3 the rapid increase in oil price leading to a peak in June 2008 is associated with positive global real activity, low spare production capacity, positive structural shocks to G3 real M2 and to BRIC real M2. The fall in oil price from July 2008 to January 2009 is associated with the global financial crisis during late 2008, recession in the U.S. over December 2007 to June 2009, and weak growth in Europe. This is reflected in Figure 3 in that the cumulative contribution of structural shocks to global real aggregate demand are extremely low in late 2008 and early 2009. OPEC decreases production target from September 2008 to January 2009. The contribution to real oil price of G3 real M2, BRIC countries' real M2, and oil specific precautionary demand are also very small or negative at the end of 2008 .

\footnotetext{
${ }^{14}$ Hamilton (2011) provides an authoritative review of oil shocks over an extended period and especially for post war period. A general strike in Venezuela reduced oil production at the end of 2002 and the beginning of 2003, and that the U.S. attack on Iraq starting in March 2003 further reduced oil production.
} 
The cumulative impact of the BRIC countries' real M2 on the real price of crude oil is substantial in the recovery of oil price during 2009 and 2010 from a low of \$41.68 in January 2009. Cumulative effects of positive structural shocks to global real aggregate demand contribute to the rise in oil price from January 2009 through April 2011 only through the latter half of the period. During 2011 oil production is disrupted in Libya and there is political turmoil in several Middle Eastern countries. Oil specific precautionary demand made a cumulative contribution to real oil prices at the end of 2009 and during 2011.

Figure 4 shows the difference in the cumulative effect on real oil price of structural shocks to BRICM2 and G3M2 over 1998:01-2011:12. A positive (negative) value for difference in cumulative effect of structural shocks to BRICM2 and G3M2 on real oil price indicates larger (smaller) effect of G3M2 on real oil price than that of BRICM2. It is striking in Figure 4 that the relative contribution to real oil price of liquidity in BRIC countries to liquidity in G3 countries (while shifting over time) is much greater since 2005 than before 2005. The relative contribution of the BRIC countries' liquidity to real oil price is particularly marked during 2007 and 2010. This reflects the fact that the influence of BRIC countries on the commodity markets has become much more important in recent years.

\subsection{Historical decomposition of global oil production}

The cumulative contribution to global oil production of the structural shocks to global oil production, global real aggregate demand, oil-specific demand, G3 real M2 and BRIC real M2 can also be calculated from the estimated SVEC model in equation (4). We note from the impulse response results that positive shocks in the BRIC countries' liquidity lead to significant and persistent increases in global oil production, and that shocks to the liquidity of the G3 countries do not. To economize on space we only report the cumulative effect on global oil production of structural shocks to BRICM2 and G3M2 in Figure 5. The relative contribution to global oil production of liquidity in BRIC countries to liquidity in G3 countries, like that of the effect on real 
oil price, has become much more important in recent years. The relative contribution of the BRIC countries' liquidity to global oil production is particularly marked since 2006.

\section{Do China and India drive the results?}

The countries, Brazil, Russia, India and China, are grouped and given the acronym BRIC on account of their being the four largest fast growing emerging economies. However, with regard to the export and import of oil and other commodities their status is very different. ${ }^{15}$ China and India are major commodity and oil importers and Brazil and Russia are major commodity exporters (Brazil is self-sufficient in energy). The net export status of the economy with regard to energy products has implications for how a rise in the price of oil would affect real M2. For this reason we will separate the BRIC countries into a group comprising China and India a group comprising Brazil and Russia. ${ }^{16}$

\subsection{Model with China/India and Brazil/Russia}

A six-variable VEC system analogous to equations (1) to (4) is specified. ${ }^{17}$ BRIC real M2 is divided into two variables. The first variable, $C I M 2_{t}$, is real M2 for China and India, and the second variable, $B R M 2_{t}$, is real $\mathrm{M} 2$ for Brazil and Russian Federation. $C I M 2_{t}$ and $B R M 2_{t}$ are $\mathrm{M} 2$ in U.S. dollars divided by the U.S. CPI.

Following equation (1), the endogenous vector-variables become:

$$
X_{t}=\left[\Delta \log \left(G O_{t}\right), \Delta \log \left(A D_{t}\right), \Delta \log \left(R P_{t}\right), \Delta \log \left(G 3 M 2_{t}\right), \Delta \log \left(C I M 2_{t}\right), \Delta \log \left(B R M 2_{t}\right)\right]
$$

And the error correction term $\left(E C T_{t}\right)$ becomes:

\footnotetext{
${ }^{15}$ Brazil and Russia are commodity rich economies including in energy products; Brazil in iron ore, coffee, soybeans, sugar, beef, oil and gas, and Russia in oil and gas, coal, gold, aluminum, nickel, gold and timber. Details on China and India as net importers and Brazil and Russia as net exporters of commodities and energy can be found at: http://www.imf.org/external/pubs/ft/weo/2012/01/pdf/c4.pdf .

${ }^{16}$ Frankel and Rose (2010) note the role of growth in India and China as a major factor in the increase in commodity prices in the 2000s. They observe that even given this influence the acceleration of commodity prices between mid-2007 and the peak around the second half of 2008 is hard to explain given the down grade in expected growth in the real economy in response to the U.S. sub-prime mortgage crisis. The surge in liquidity in the BRIC countries, and particularly China, is consistent with the strong rise in oil and commodity prices over 2007-2008. For example BRIC M2 surged over $28 \%$ between June 2007 and September 2008, and that for China by over 33\% over the same period.

${ }^{17}$ Note that $C I M 2_{t}$ and $B R M 2_{t}$ are $I(1)$ variables as evidence from figure 1 a and confirm by the ADF, DF-GLS. PP and KPSS. The standard VAR Johansen trace and eight values test of these six variables VAR-systems support the hypothesis of one cointegration vector among these variables.
} 


$$
\begin{gathered}
E C T_{t}=\log \left(G O_{t}\right)-\beta-\psi \log \left(A D_{t}\right)-\gamma \log \left(R P_{t}\right)-\delta \log \left(G 3 M 2_{t}\right)-\varphi \log \left(C I M 2_{t}\right)- \\
\vartheta \log \left(B R M 2_{t}\right)
\end{gathered}
$$

Analogous to equation $4,{ }^{18}$ the identification restrictions in $B_{o} X_{t}$ vectors become in:

$$
B_{o} X_{t}=\left[\begin{array}{cccccc}
1 & 0 & 0 & 0 & 0 & 0 \\
-b_{20} & 1 & 0 & 0 & 0 & 0 \\
-b_{30} & -b_{31} & 1 & 0 & 0 & 0 \\
-b_{40} & -b_{41} & -b_{42} & 1 & 0 & 0 \\
-b_{50} & -b_{51} & -b_{52} & -b_{53} & 1 & 0 \\
-b_{60} & -b_{61} & -b_{62} & -b_{63} & -b_{64} & 1
\end{array}\right]\left[\begin{array}{c}
\Delta \log \left(G O_{t, 10}\right) \\
\Delta \log \left(A D_{t, 20}\right) \\
\Delta \log \left(R P_{t, 30}\right) \\
\Delta \log \left(G 3 M 2_{t, 40}\right) \\
\Delta \log \left(C I M 2_{t, 50}\right) \\
\Delta \log \left(B R M 2_{t, 60}\right)
\end{array}\right]
$$

\subsection{Results for China/India and Brazil/Russia}

Figure 6 shows the responses of the variables in the model 2, the six variable SVEC, to onestandard deviation structural innovations. The finding that an innovation in BRIC countries' real M2 has significant effects on oil production, on global aggregate demand and on real oil price is refined. The responses of global oil production, global real aggregate demand and real oil prices to an unanticipated shock to China's and India's real M2 are both large and statistically significant (in the first three rows of column 5 in Figure 6) and in accord with the results noted for the BRIC countries overall .

The response of global real aggregate demand to an unanticipated shock to Brazil's and Russia's real M2 is also positive, large and statistically significant, but the response of real oil price is not (in the second and third rows of column 6 in Figure 6). The responses of global oil production Brazil's and Russia's real M2 is negative at first and statistically significant for three months. The effect of real M2 on global oil production is different between shocks to liquidity arising in China and India compared to Brazil and Russia.

China and India drive the results for the effect of BRIC countries real M2 on real oil price and global oil production. China and India and Brazil and Russia reinforce one another on the effect of BRIC countries liquidity on global real aggregate demand. The responses of global oil production,

\footnotetext{
${ }^{18}$ The order of the M2 variables in the VAR is determined by size, with the larger aggregates being placed earlier.
} 
global real aggregate demand and real oil prices to an unanticipated shock to G3 real M2 are not as large and are not statistically significant (in the first three rows of column 4 in Figure 6).

A notable difference in results arises between the effects of global real aggregate demand and real oil price on $C I M 2_{t}$ and $B R M 2_{t}$ due to the difference between the two groups of emerging countries in terms of their differences as commodity importers/exporters. The real M2 of Brazil and Russia increases significantly with a rise in real oil price and increases (but not significantly) with a rise global real aggregate demand. In contrast, the real M2 of China and India decreases significantly with a rise in real oil price and with a rise global real aggregate demand. ${ }^{19}$

\section{Robustness analysis}

\subsection{Alternative variables, lag length, variable ordering}

Several checks confirmed the robustness of both model 1 (equation 1 to 4 ) and model 2 (equations 1, 5, 6 and 7). First of all, we substitute the variable global industrial production (as measure of real aggregate demand), by global demand for real aggregate demand, based on Kilian's (2009) global index of dry cargo single voyage freight rates. This index represents the global demand for commodities. Kilian's (2009) indicator of global activity an index already constructed to be stationary. (It is a business cycle index). This alternative specification does not change our general results about the dominant effect on oil prices of BRIC countries' liquidity, particularly the liquidity of China and India, compared to the liquidity of the G3 countries.

A lag length sensitivity of our SVEC models is test by using the Akaike Information Criterion (AIC) rather than the SBC. The AIC selected three lags rather than the two selected by the SBC. This exercise suggests that our SVEC models provided similar results using either two or three lags.

\footnotetext{
${ }^{19}$ These findings of monetary contraction in China and India are consistent with those found for the U.S. by Kilian and Lewis (2011) that in response to positive innovations in aggregate demand shock and oil market-specific demand there are significant and sustained increase in the federal funds rate. Fan et al. (2011) observe that the central bank of China maintains that the money supply is the main monetary tool in China, a view confirmed by the analysis in their paper. Sánchez-Fung (2012) finds that monetary aggregates better represent monetary policy than interest rates in China.
} 
The order of the first two variables in either equation 4 or equation 7 is clearly established by international studies such as Kilian (2009) and Kilian and Lewis (2011). However, whether the real oil $\Delta \log \left(R P_{t}\right)$ or the $\mathrm{M} 2$ variables $\Delta \log \left(G 3 M 2_{t}\right)$ and $\Delta \log \left(B R I C_{t}\right)$ in model 1 and the real oil $\Delta \log \left(R P_{t}\right)$ or the $\mathrm{M} 2$ variables $\Delta \log \left(G 3 M 2_{t}\right), \Delta \log \left(C I M 2_{t}\right) \Delta \log \left(B R M 2_{t}\right)$ in model 2 is less clear. Consequently, we re-estimate the models by switching the order of the $\Delta \log \left(R P_{t}\right)$ and the M2 variables to find that general results remain unchanged using either order.

\subsection{Autocorrelation, heteroskedasticity and stability condition}

To test for autocorrelation and heteroskedasticity, the residual serial correlation LM test and the VAR residual heteroskedasticity test are carried out in both models. The null hypothesis of both, no serial correlation and no heteroskedasticity of the joint combinations of all error term products cannot be rejected at the 5\% level (respectively).Consequently, the present of either autocorrelation and/or heteroskedasticity are discarded. The stability condition ${ }^{20}$ for the VEC model, with $r$ cointegrating equation and $\mathrm{k}$ endogenous variables, requires that at most $\mathrm{k}-\mathrm{r}$ roots should be equal to unity, while the other roots must lie inside the unit root circle. Consequently, the inverse roots of the characteristic AR polynomial test are performed. This test finds that this condition is satisfied for both model 1 and model 2 .

\section{Conclusion}

The BRIC countries have provided dramatic increases in liquidity in recent years. Unanticipated increases in the BRIC countries' real M2 lead to significant and persistent increases in global oil production, global real aggregate demand and real oil prices. Increases the G3 countries' real M2 also lead to increases in these variables, but the effects are not statistically significant. After the shock to BRIC real M2, the increase in global oil production builds up and is statistically significant after the fifth month and remains so for fifteen months. The rise in global real aggregate

\footnotetext{
${ }^{20}$ For more detail see Enders, Applied Econometric, p. 266.
} 
demand is statistically significant over all horizons. The increase in real oil prices is statistically significant for sixteen months. The relative contribution to real oil price of liquidity in BRIC countries to liquidity in developed countries is much greater since 2005 than before 2005. The rebound in oil price during 2009 is mostly due to strong effects of shocks to liquidity in the BRIC countries.

China and India drive the results for the effect of BRIC countries' liquidity on real oil price and global oil production. China and India and Brazil and Russia reinforce one another on the effect of BRIC countries' liquidity on global real aggregate demand. Due to the difference between countries as commodity importers/exporters, the liquidity of Brazil and Russia increases significantly with a rise in real oil price whereas that of China and India decreases significantly with a rise in real oil price.

Results are consistent with the fact that the influence of the BRIC countries on commodity markets has become much more important in recent years. The analysis helps understand the causes of movement in oil prices over the last twenty years and assists in assessing the importance of the BRIC economies in the upsurge of the real price of crude oil. 


\section{References}

Adalid, R., Detken, C., 2007. Liquidity shocks and asset price boom/bust cycles. ECB Working Paper 732, European Central Bank, Frankfurt a.M.

Baks, K., Kramer, C.F., 1999. Global liquidity and asset prices: Measurement, implications, and spillovers. IMF Working Paper 99/168, International Monetary Fund, Washington, D.C.

Barsky, R.B., Kilian, L., 2002. Do We Really Know that Oil Caused the Great Stagflation? A Monetary Alternative, in Bernanke, B.S., Rogoff, K. (Eds.), NBER Macroeconomics Annual 2001, MIT Press: Cambridge, MA, pp. 137-183.

Belke, A., Bordon, I., Hendricks, T., 2010. Global liquidity and commodity prices-a cointegrated VAR approach for OECD countries. Applied Financial Economics 20, 227-242.

Belke, A., Orth, W., Setzer, R., 2010. Liquidity and the dynamic pattern of asset price adjustment: A global view. Journal of Banking and Finance 34, 1933-1945.

Bernanke B.S., Gertler, M., Watson, M.W., 1997. Systematic Monetary Policy and the Effects of Oil Price Shocks. Brookings Papers on Aggregate demand 1, 91-142.

Bodenstein, M., Erceg, C.J., Guerrieri, L., 2008. Optimal Monetary Policy with Distinct Core and Headline Inflation Rates. Journal of Monetary Economics 55(Supplement), S18-S33.

Bodenstein, M., Guerrieri, L., Kilian, L., 2012. Monetary policy responses to oil price fluctuations. CEPR Discussion Papers 8928, C.E.P.R. Discussion Papers.

Brana, S., Djigbenou, M.-L., Prat, S., 2012. Global excess liquidity and asset prices in emerging countries: A PVAR approach. Emerging Markets Review 13(3), 256-267.

D’Agostino, A., Surico, P., 2009. Does global liquidity help to forecast US inflation? Journal of Money, Credit and Banking 41 (2/3), 479-489.

Darius, R., Radde, S., 2010. Can Global Liquidity Forecast Asset Prices? IMF Working Paper 10/196, International Monetary Fund, Washington, D.C.

Elekdag, S., Lalonde, R., Laxton, D., Muir, D., Pesenti, P., 2008. Oil Price Movements and the Global Economy: A Model-Based Assessment. NBER Working Paper No. 13792.

Enders, W., 2004. Applied Econometric Time Series, second ed. John Wiley and Sons, New York.

Engle, R.F., Granger, C.W.J., 1987. Cointegration and Error-Correction: Representation, Estimation, and Testing. Econometrica 55, 251-276.

Fan, L., Yu, Y., Zhang, C., 2011. An empirical evaluation of China's monetary policies. Journal of Macroeconomics 33 (2), 358-371.

Frankel, J.A., Rose, A.K., 2010. Determinants of Agricultural and Mineral Commodity Prices in: Fry, R., Jones, C., Kent, C., (Eds.), Inflation in an Era of Relative Price Shocks, Sydney, pp. 9-51. 
Gerdesmeier, D., Roffia, B., Reimers, H.-E., 2009. Asset price misalignments and the role of money and credit. ECB Working Paper 1068, European Central Bank, Frankfurt a.M.

Gillman, M., Nakov, A., 2009. Monetary Effects on Nominal Oil Prices. North American Journal of Economics and Finance 20, 239-254.

Greiber, C., Setzer, R., 2007. Money and housing: Evidence for the euro area and the US. Deutsche Bundesbank Discussion Paper Series 1: Economic Studies 07/12, Frankfurt a.M.

Hamilton, J.D., 1983. Oil and the Macroeconomy since World War II. Journal of Political Economy 91, 228-248.

Hamilton, J.D., 2009. Causes and Consequences of the Oil Shock of 2007-08. Brookings Papers on Economic Activity 1, Spring, 215-261.

Hamilton, J.D., 2011. Historical Oil Shocks. NBER Working Paper No. 16790. Forthcoming in The Routledge Handbook of Major Events in Economic History, Parker, R.E., Whaples, R.M., (Eds.), Routledge, 2013.

Kilian, L., 2009. Not All Oil Price Shocks Are Alike: Disentangling Demand and Supply Shocks in the Crude Oil Market. American Economic Review 99, 1053-1069.

Kilian, L., Hicks, B., 2012. Did Unexpectedly Strong Economic Growth Cause the Oil Price Shock of 2003-2008? Journal of Forecasting, forthcoming. DOI: 10.1002/for.2243.

Kilian, L., Lewis, L.T., 2011. Does the Fed Respond to Oil Price Shocks? The Economic Journal $121,1047-1072$

Kim, I., Loungani, P., 1992. The role of energy in real business cycle models. Journal of Monetary Economics 29, 173-89.

Leduc, S., Sill, K., 2007. Monetary Policy, Oil Shocks, and TFP: Accounting for the Decline in US Volatility. Review of Economic Dynamics 10, 595-614.

Lee, K., Ni, S., Ratti, R.A., 1995. Oil shocks and the Marcoeconomy: the role of price variability. Energy Journal 16, 39-56.

Nakov, A., Pescatori, A., 2010. Monetary Policy Trade-Offs with a Dominant Oil Producer. Journal of Money, Credit and Banking 42, 1-32.

Ratti, R.A., Vespignani, J. L., 2012. Crude Oil Prices: China’s Influence Over 1996-2011 Working paper.

Ruffer. R., Stracca, L., 2006. What is global excess liquidity, and does it matter? ECB Working Paper 696, European Central Bank, Frankfurt a. M.

Sánchez-Fung, J. R., 2012. Examining the role of monetary aggregates in China. Bank of Finland Discussion Papers 18/2012.

Sims, C.A., 1980. Macroeconomics and Reality. Econometrica 48, 1-48. 
Sousa, J., Zaghini, A., 2007. Global Monetary Policy Shocks in the G5: A SVAR Approach. Journal of International Financial Markets, Institutions and Money 17, 403-419.

Table 1: Test for unit roots 1997:1-2011:12:

\begin{tabular}{ccccc}
\hline \hline Variables & ADF & DF-GLS & PP & KPSS \\
\hline $\log \left(G O_{t}\right)$ & 1.104 & 0.620 & -1.104 & $1.637^{* * * *}$ \\
$\log \left(A D_{t}\right)$ & -2.056 & -0.363 & -2.062 & $1.157^{* * * *}$ \\
$\log \left(R P_{t}\right)$ & 1.516 & -0.794 & -1.119 & $1.516^{* * * *}$ \\
$\log \left(G 3 M 2_{t}\right)$ & -0.263 & 1.035 & 0.138 & $1.675^{* * * *}$ \\
$\log \left(B R I C M 2_{t}\right)$ & 3.365 & 3.226 & 3.680 & $1.725^{* * *}$ \\
$\Delta \log \left(G O_{t}\right)$ & $-11.550^{* * *}$ & $-3.901^{* * *}$ & $-13.815^{* * *}$ & 0.034 \\
$\Delta \log \left(A D_{t}\right)$ & $-4.742^{* * *}$ & $-3.737^{* * *}$ & $-7.447^{* * * *}$ & 0.091 \\
$\Delta \log \left(R P_{t}\right)$ & $-10.620^{* * *}$ & $-3.610^{* * *}$ & $-10.618^{* * *}$ & 0.059 \\
$\Delta \log \left(G 3 M 2_{t}\right)$ & $-10.768^{* * *}$ & $-2.643^{* * *}$ & $-10.567^{* * *}$ & 0.125 \\
$\Delta \log \left(B R I C M 2_{t}\right)$ & $-12.225^{* * *}$ & -0.536 & $-12.339^{* * *}$ & $0.560^{* *}$ \\
\hline \hline
\end{tabular}

The null hypothesis for the ADF, DF-GLS and PP is the variable has a unit root and the null hypothesis for the KPSS is the variable is stationary.

The first difference of the series is indicated by $\Delta$.The lag selection criteria for the ADF, DF-GLS and PP tests is based on Schwarz information Criteria (SIC) and for the KPSS is the Newey-West Bandwidth with constant and linear trend. $*, * *, * * *$ indicates rejection of the null hypothesis at $1 \%, 5 \%$ and $10 \%$, levels of significance.

Table 2: VAR Johansen cointegration test summary:

\begin{tabular}{cccc}
\hline Cholesky lower triangle matrix order; & & \\
$\log \left(G O_{t}\right), \log \left(A D_{t}\right), \log \left(R P_{t}\right), \log \left(G 3 M 2_{t}\right), \log \left(B R I C M 2_{t}\right)$ & \\
\hline Data Trend: & None & None & Linear \\
\hline Test Type & No Intercept & Intercept & Intercept \\
& No Trend & No Trend & No Trend \\
Trace & 1 & 1 & 1 \\
Max-Eig & 1 & 1 & 1 \\
\hline
\end{tabular}

*Critical values based on MacKinnon-Haug-Michelis (1999)

**Selected $(0.05$ level*) Number of Cointegrating Relations by Model 
Table 3: VEC model parameters estimated:

\begin{tabular}{|c|c|c|c|c|c|}
\hline & $\Delta \log \left(G O_{t}\right)$ & $\Delta \log \left(A D_{t}\right)$ & $\Delta \log \left(R P_{t}\right)$ & $\Delta \log \left(G 3 M 2_{t}\right)$ & $\Delta \log \left(B R I C M 2_{t}\right)$ \\
\hline $\mathrm{AD}$ & $\begin{array}{l}-0.07 \\
(0.050)\end{array}$ & - & - & - & - \\
\hline $\mathrm{RP}$ & $\begin{array}{l}0.822 \\
(0.745)\end{array}$ & $\begin{array}{l}-2.53^{* * *} \\
(1.111)\end{array}$ & - & - & - \\
\hline G3M2 & $\begin{array}{l}-0.061 \\
(0.140)\end{array}$ & $\begin{array}{l}-2.532 \\
(1.112)\end{array}$ & $\begin{array}{l}0.013 \\
(0.014)\end{array}$ & - & - \\
\hline BRICM2 & $\begin{array}{l}0.249 * * * \\
(0.087)\end{array}$ & $\begin{array}{l}-0.020 \\
(0.131)\end{array}$ & $\begin{array}{l}-0.019 * * \\
(0.008)\end{array}$ & $\begin{array}{l}-0.001 \\
(0.046)\end{array}$ & \\
\hline$\Delta \log \left(G O_{t-1}\right)$ & $\begin{array}{l}-0.170 * \\
(0.079)\end{array}$ & $\begin{array}{l}-0.063 \\
(0.053)\end{array}$ & $\begin{array}{l}-0.940 \\
(0.797)\end{array}$ & $\begin{array}{l}-0.421 * * * \\
(0.148)\end{array}$ & $\begin{array}{l}0.098 \\
(0.094)\end{array}$ \\
\hline$\Delta \log \left(G O_{t-2}\right)$ & $\begin{array}{l}-0.171 \\
(0.07)\end{array}$ & $\begin{array}{l}-0.063 \\
(0.050)\end{array}$ & $\begin{array}{l}-0.940 \\
(0.797)\end{array}$ & $\begin{array}{l}-0.420 * * * \\
(0.148)\end{array}$ & $\begin{array}{l}0.098 \\
(0.094)\end{array}$ \\
\hline$\Delta \log \left(A D_{t-1}\right)$ & $\begin{array}{l}0.112 \\
(0.110)\end{array}$ & $\begin{array}{l}0.290 * * * \\
(0.074)\end{array}$ & $\begin{array}{l}1.992 * \\
(1.110)\end{array}$ & $\begin{array}{l}0.396 * \\
(0.206)\end{array}$ & $\begin{array}{l}-0.126 \\
(0.131)\end{array}$ \\
\hline$\Delta \log \left(A D_{t-2}\right)$ & $\begin{array}{l}0.101 \\
(0.105)\end{array}$ & $\begin{array}{l}0.301 * * * \\
(0.070)\end{array}$ & $\begin{array}{l}0.929 \\
(1.054)\end{array}$ & $\begin{array}{l}-0.362 * \\
(0.196)\end{array}$ & $\begin{array}{l}-0.101 \\
(0.125)\end{array}$ \\
\hline$\Delta \log \left(R P_{t-1}\right)$ & $\begin{array}{l}-0.004 \\
(0.007)\end{array}$ & $\begin{array}{l}0.015 * * * \\
(0.005)\end{array}$ & $\begin{array}{l}0.107 \\
(0.079)\end{array}$ & $\begin{array}{l}-0.022 \\
(0.014)\end{array}$ & $\begin{array}{l}0.008 \\
(0.009)\end{array}$ \\
\hline$\Delta \log \left(R P_{t-2}\right)$ & $\begin{array}{l}0.002 \\
(0.008)\end{array}$ & $\begin{array}{l}0.003 \\
(0.005)\end{array}$ & $\begin{array}{l}0.041 \\
(0.081)\end{array}$ & $\begin{array}{l}0.0136 \\
(0.015)\end{array}$ & $\begin{array}{l}0.007 \\
(0.009)\end{array}$ \\
\hline$\Delta \log \left(G 3 M 2_{t-1}\right)$ & $\begin{array}{l}0.000 \\
(0.040)\end{array}$ & $\begin{array}{l}-0.032 \\
(0.027)\end{array}$ & $\begin{array}{l}0.003 \\
(0.404)\end{array}$ & $\begin{array}{l}0.264 * * * \\
(0.075)\end{array}$ & $\begin{array}{l}0.181 * * * \\
(0.048)\end{array}$ \\
\hline$\Delta \log \left(G 3 M 2_{t-2}\right)$ & $\begin{array}{l}-0.013 \\
(0.040)\end{array}$ & $\begin{array}{l}-0.021 \\
(0.026)\end{array}$ & $\begin{array}{l}0.164 \\
(0.401)\end{array}$ & $\begin{array}{l}-0.008 \\
(0.074)\end{array}$ & $\begin{array}{l}-0.018 \\
(0.047)\end{array}$ \\
\hline$\Delta \log \left(B R I C M 2_{t-1}\right)$ & $\begin{array}{l}0.087 \\
(0.067)\end{array}$ & $\begin{array}{l}0.071 * \\
(0.045)\end{array}$ & $\begin{array}{l}1.313 * \\
(0.677)\end{array}$ & $\begin{array}{l}-0.158 \\
(0.126)\end{array}$ & $\begin{array}{l}0.078 \\
(0.080)\end{array}$ \\
\hline$\Delta \log \left(B R I C M 2_{t-2}\right)$ & $\begin{array}{l}0.061 \\
(0.066)\end{array}$ & $\begin{array}{l}0.123 * * * \\
(0.044)\end{array}$ & $\begin{array}{l}1.164 * \\
(0.665)\end{array}$ & $\begin{array}{l}-0.107 \\
(0.123)\end{array}$ & $\begin{array}{l}0.165 * \\
(0.079)\end{array}$ \\
\hline $\mathrm{C}$ & $\begin{array}{l}-0.001 \\
(0.001)\end{array}$ & $\begin{array}{l}-0.002 * * \\
(0.001)\end{array}$ & $\begin{array}{l}-0.031 * * \\
(0.014)\end{array}$ & $\begin{array}{l}0.006 * * * \\
(0.002)\end{array}$ & $\begin{array}{l}0.010 * * * \\
(0.002)\end{array}$ \\
\hline $\mathrm{ECT}_{t-1}$ & $\begin{array}{l}-0.114 * * * \\
(0.036)\end{array}$ & $\begin{array}{l}0.004 \\
(0.024)\end{array}$ & $\begin{array}{l}0.570+ \\
(0.369)\end{array}$ & $\begin{array}{c}0.000 \\
(0.068)\end{array}$ & $\begin{array}{l}0.068+ \\
(0.043)\end{array}$ \\
\hline $\mathrm{R} 2$ & 0.145 & 0.482 & 0.153 & 0.189 & 0.140 \\
\hline Adj. R2 & 0.088 & 0.447 & 0.097 & 0.135 & 0.083 \\
\hline F-statistic & 2.546 & 13.96 & 2.729 & 3.514 & 2.449 \\
\hline
\end{tabular}

$* * *, * *,+$ indicates coefficients are statistically significant at 1\%, 5\%,10\% and 15\% respectively. Lag order was selected by Schwarz Bayesian Criterion (SBC). Standard errors are given in parenthesis. 
Figure 1a: BRIC countries Nominal M2 in Billions of U.S. dollars: 1997:01-2011:12.

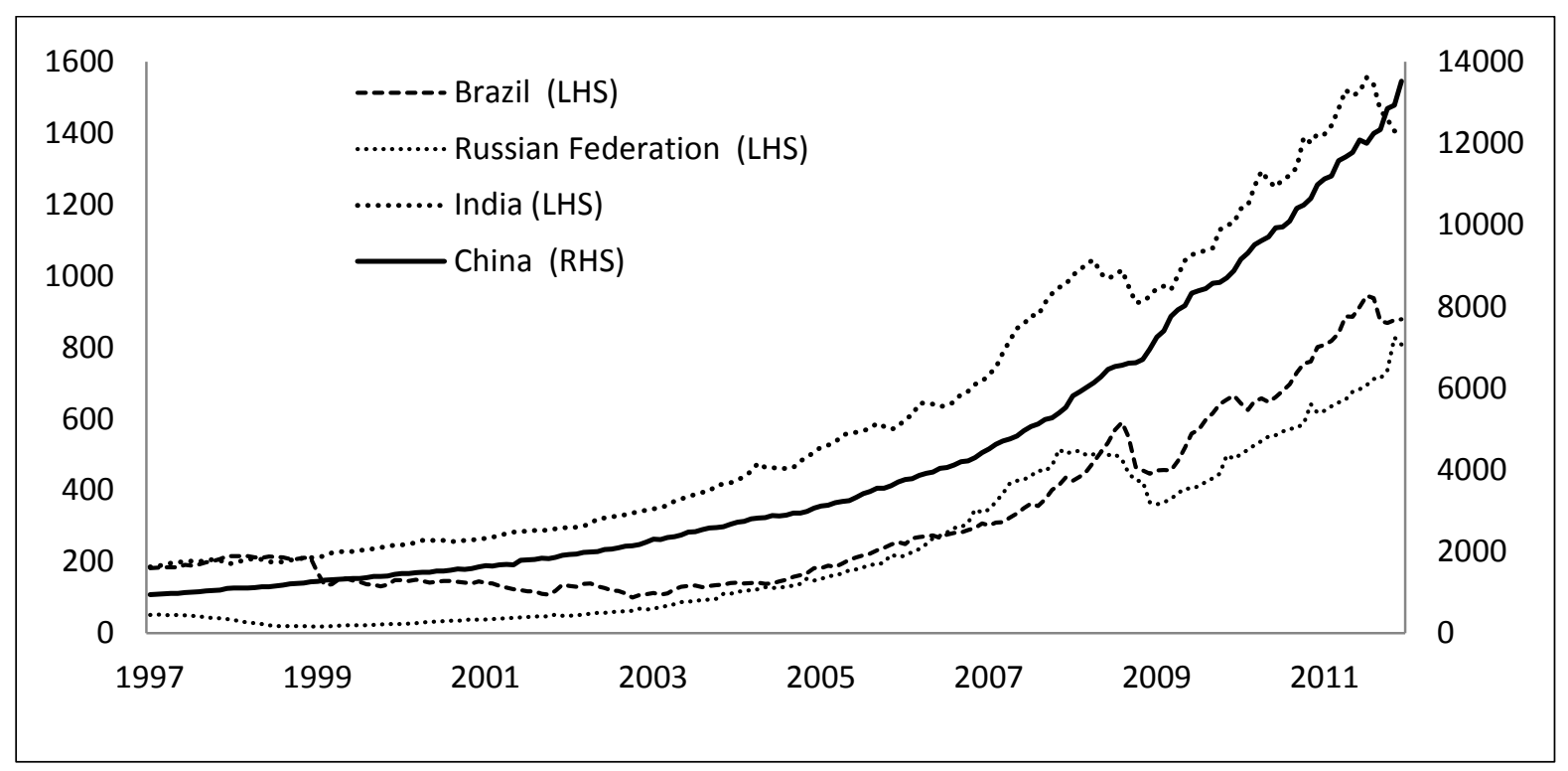

Figure 1b: G3 countries Nominal M2 in Billions of U.S. dollars: 1997:01-2011:12.

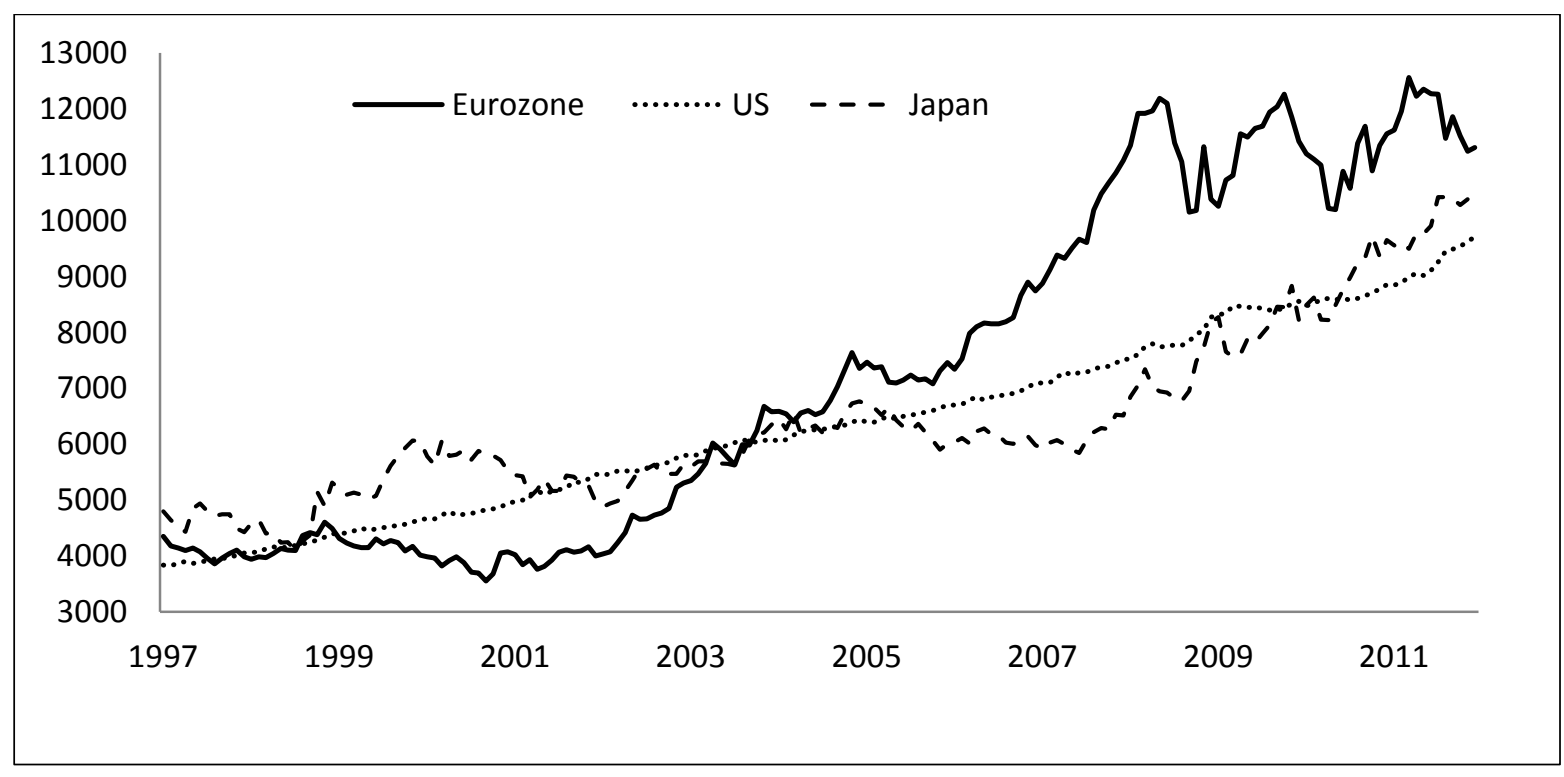


Figure 1c: BRIC and G3 M2 in U.S. dollars as percentage of Global liquidity: 1997:01-2011:12.

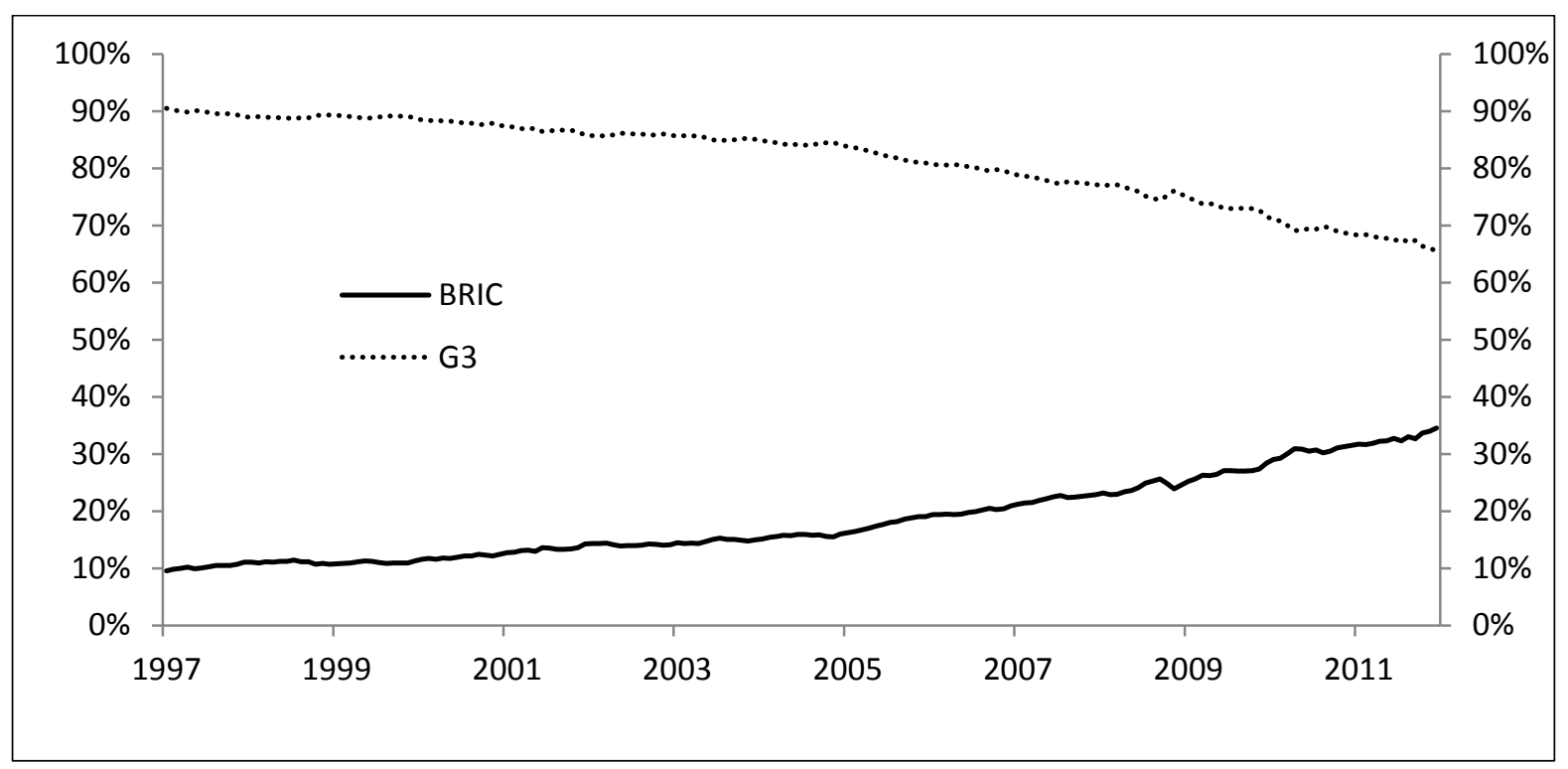

Figure 1d: BRIC and G3 M2-Nominal GDP in U.S. dollars ratio: 1997-2011.

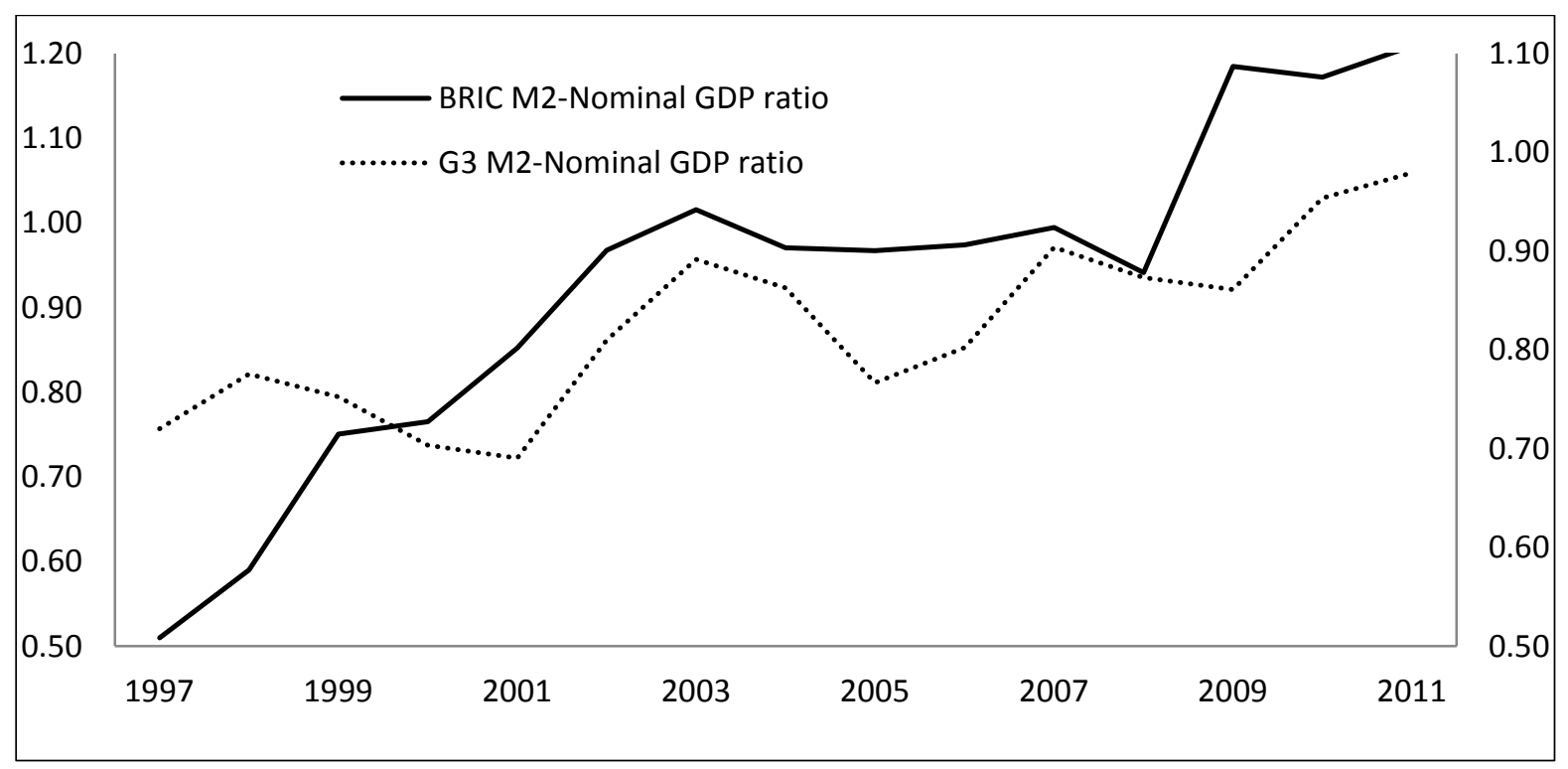


Figure 1e: Real oil prices and China and India real M2: 1997:01-2011:12.

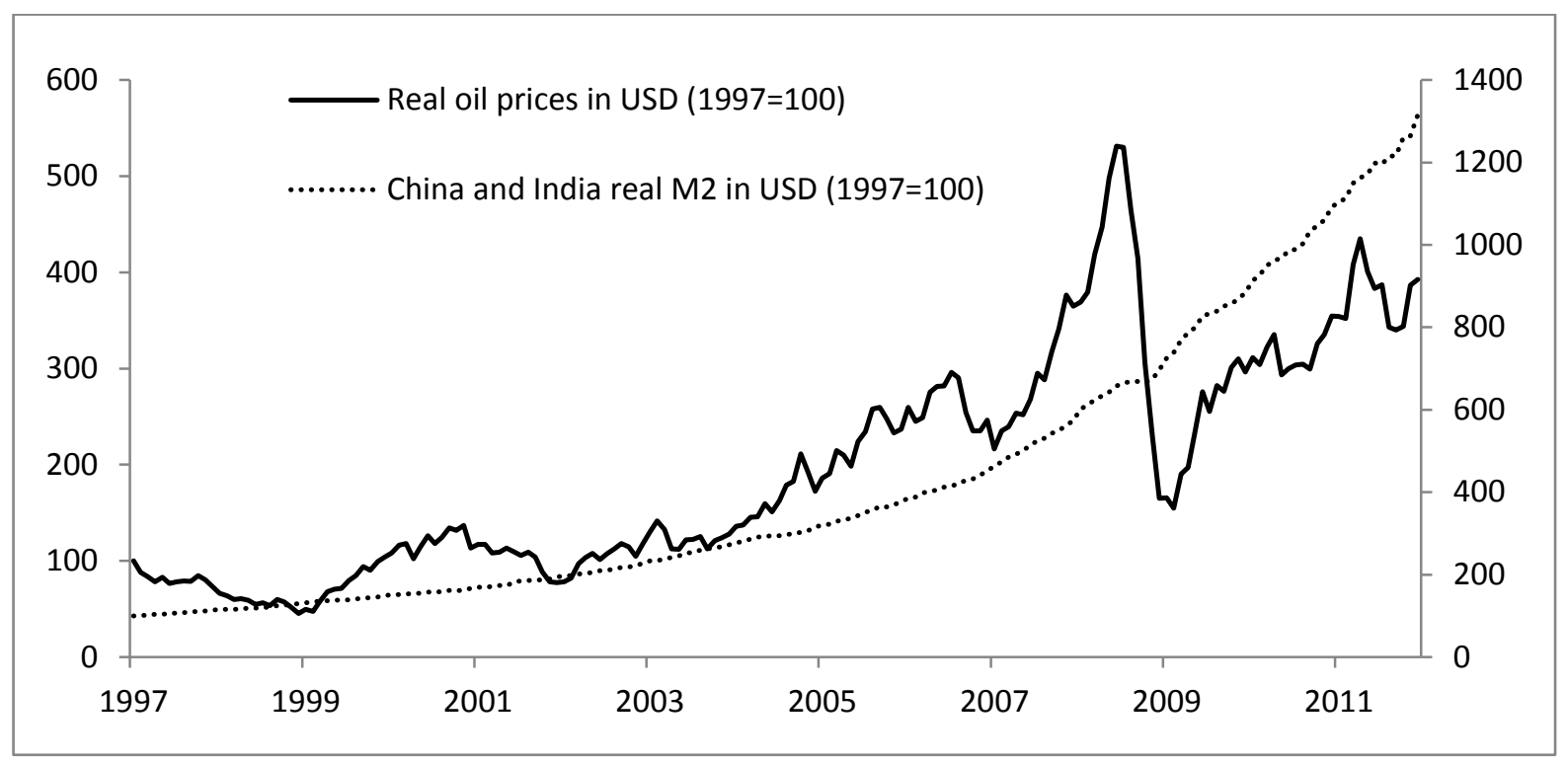

Notes: The BRIC countries are Brazil, Russian federation, India and China, and the G3 countries are the U.S., Eurozone and Japan. Data are monthly over 1997:01-2011:12, nominal variables are in U.S. dollars, and real variables are nominal values divided by U.S. CPI. 
Figure 2: The impulse response effects of the structural shocks: 1997:01-2011:12
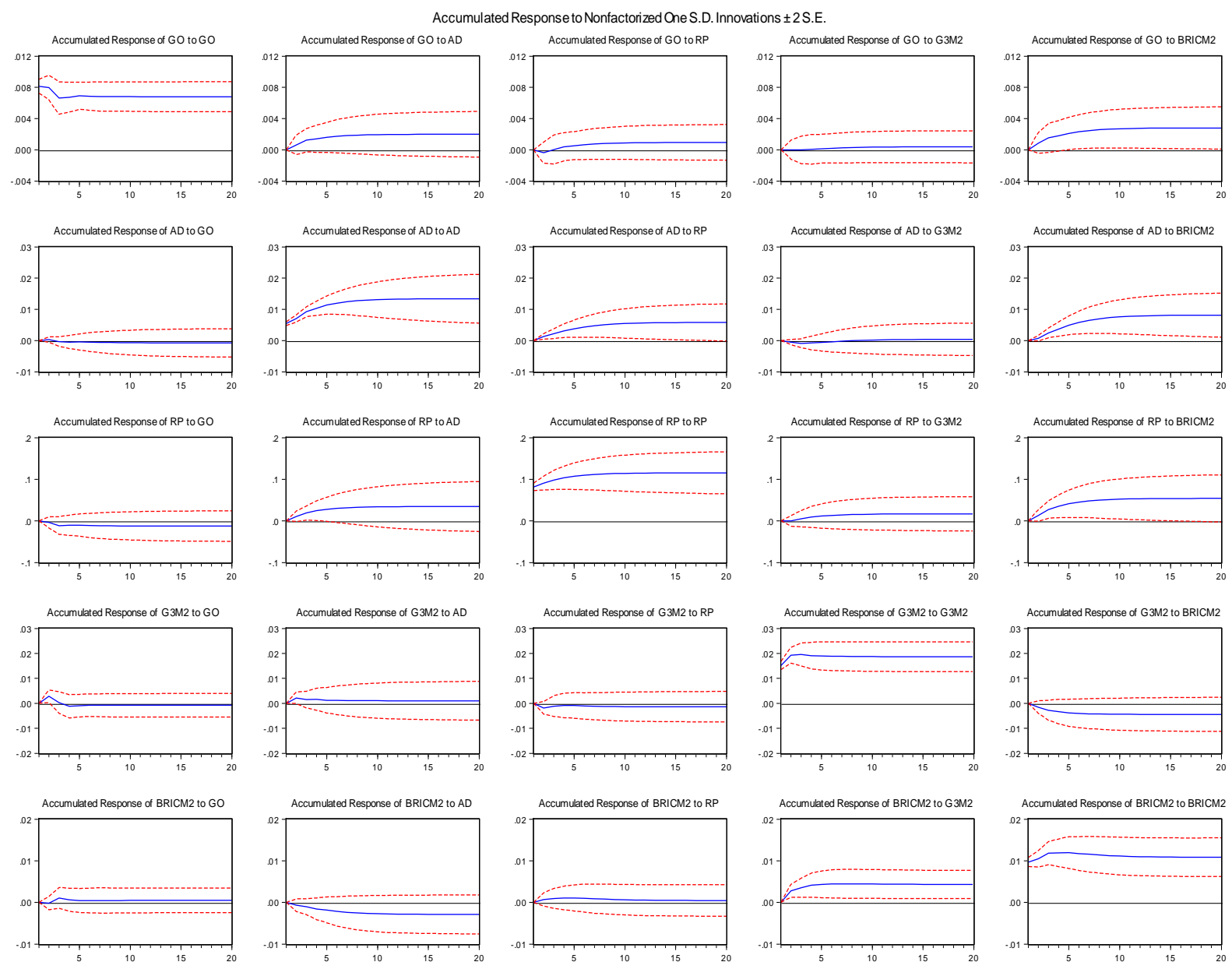

Notes: $G O$ is global oil production, $A D$ is global aggregate demand shock, $R P$ is real oil price, $G 3 M 2$ is $\mathrm{M} 2$ of $\mathrm{G} 3$ countries (U.S., Eurozone and Japan), and BRICM2 is the M2 of the BRIC countries (Brazil, Russia, India and China). The M2 variables and oil prices are deflated by U.S. CPI. 
Figure 3: Cumulative effect of structural shocks on real price of oil (annual average)
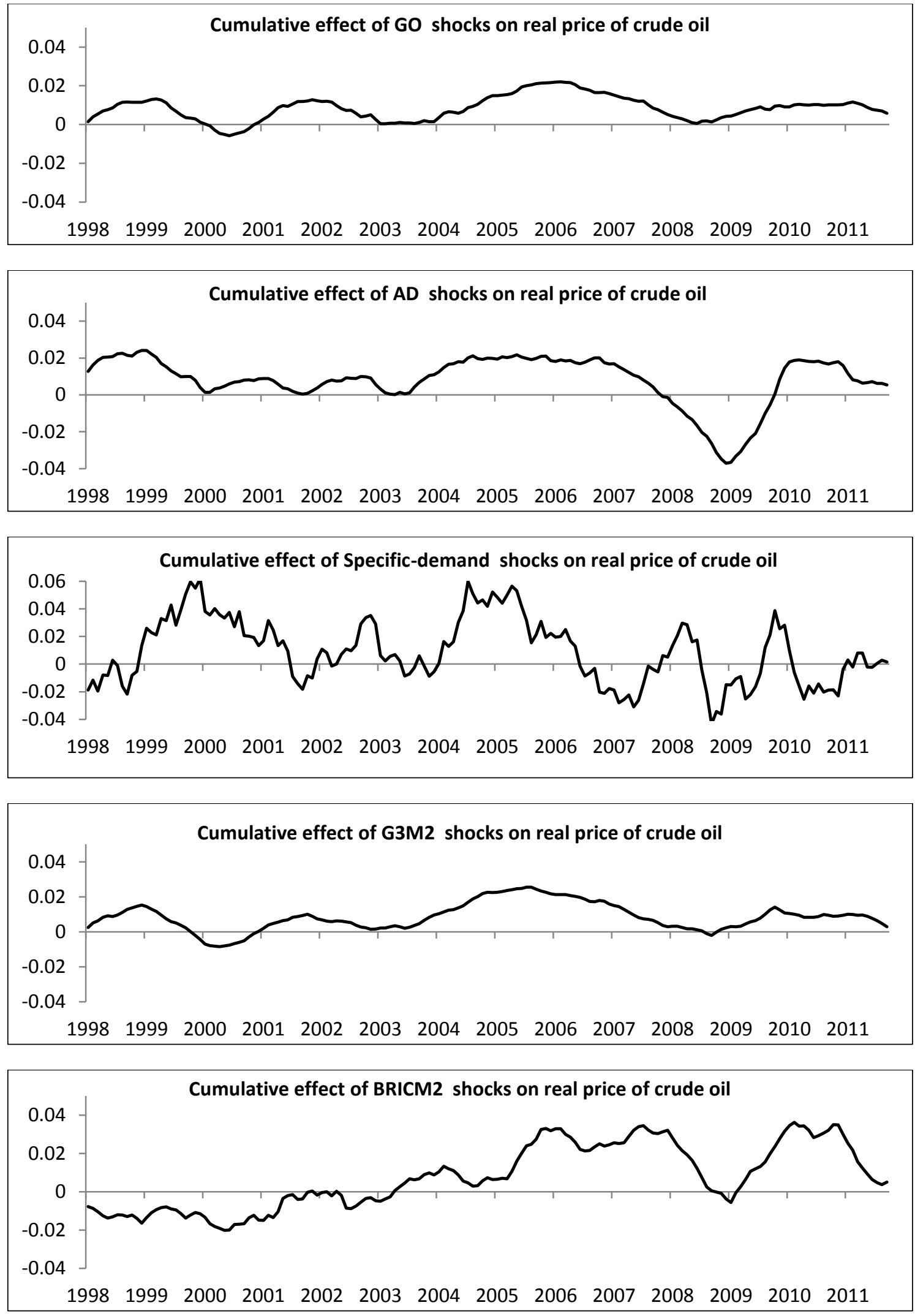

Notes: $\mathrm{GO}$ is global oil production, $\mathrm{AD}$ is global aggregate demand shock, $\mathrm{RP}$ is real oil price, G3M2 is $\mathrm{M} 2$ of G3 countries (U.S., Eurozone and Japan), and BRICM2 is the M2 of the BRIC countries (Brazil, Russia, India and China). The M2 variables and oil prices are deflated by U.S. CPI. 
Figure 4: Difference in cumulative effect on real oil price of structural shocks to BRICM2 and G3M2

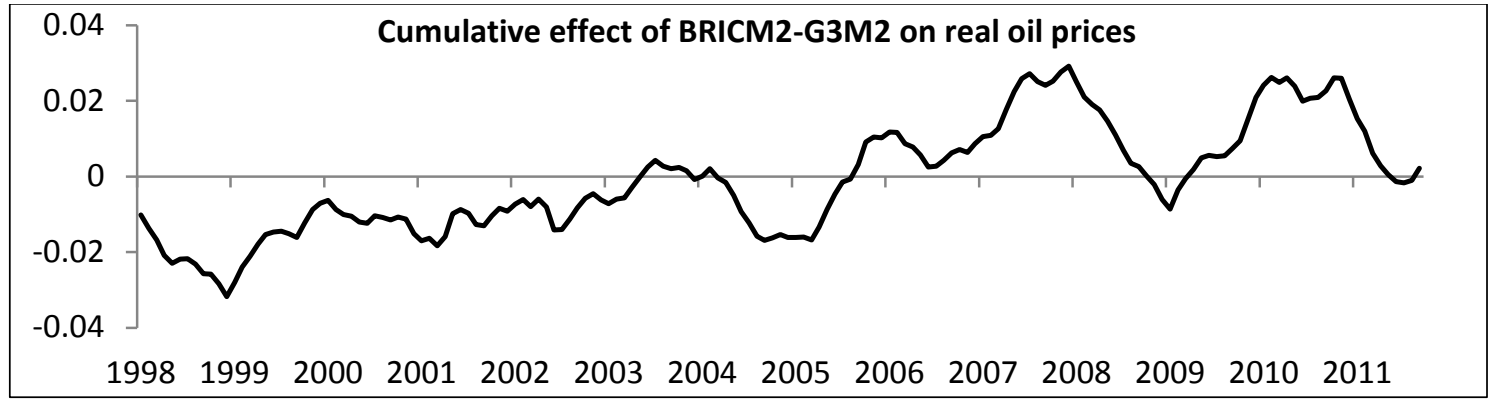

Notes: A positive (negative) value for difference in cumulative effect of structural shocks to BRICM2 and G3M2 on real oil price indicates larger (smaller) effect of G3M2 on real oil price than that of BRICM2. G3M2 is M2 of G3 countries (U.S., Eurozone and Japan), and BRICM2 is the M2 of the BRIC countries (Brazil, Russia, India and China). The M2 variables and oil prices are deflated by U.S. CPI.

Figure 5: Cumulative contribution to global oil production of BRICM2 and G3M2 structural shocks

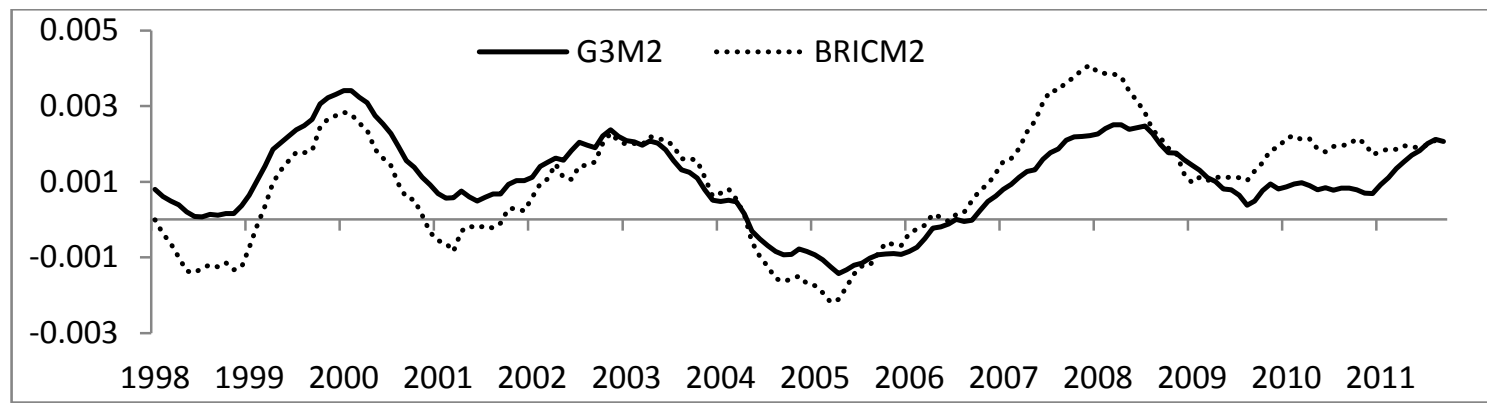

Notes: Cumulative effect on global oil production of structural shocks of BRICM2 and G3M2. G3M2 is M2 of G3 countries (U.S., Eurozone and Japan), and BRICM2 is the M2 of the BRIC countries (Brazil, Russia, India and China). The M2 variables are deflated by U.S. CPI. 
Figure 6. The impulse response effects of the structural shocks for China and India, and for Brazil and Russia
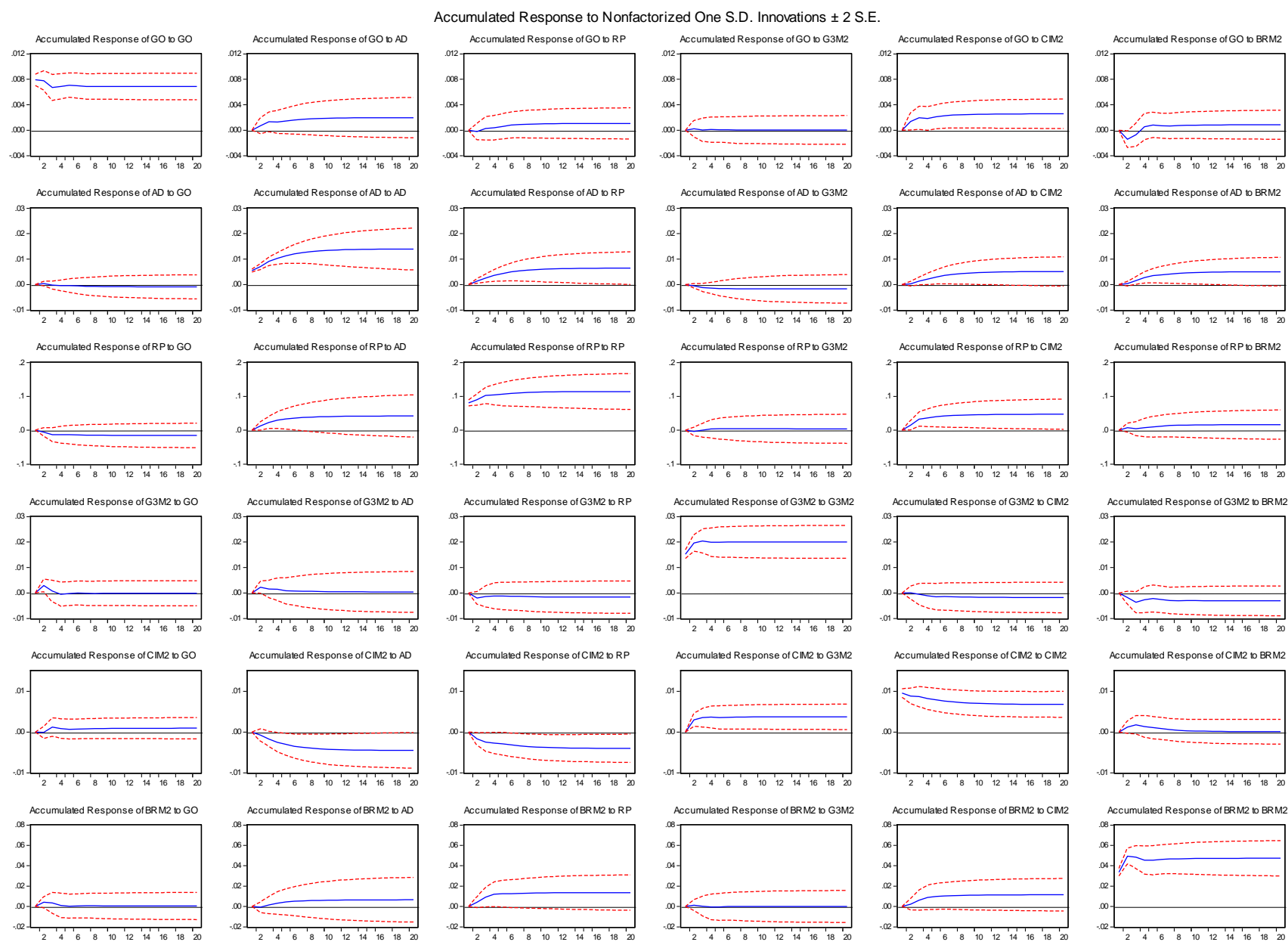

Notes: GO is global oil production, AD is global aggregate demand shock, RP is real oil price, G3M2 is M2 of G3 countries (U.S., Eurozone and Japan), CIM2 is the M2 of China and India, and BRM2 is the M2 of Brazil and Russia. The M2 variables and oil prices are deflated by U.S. CPI. 


\section{School of Economics and Finance Discussion Papers}

2012-11

2012-10

2012-09

2012-08

2012-07

2012-06

2012-05

2012-04

2012-03

2012-02

2012-01

2011-06

2011-05

2011-04

2011-03

2011-02

2011-01

2010-12

2010-11

2010-10

2010-09

2010-08

2010-07

2010-06

2010-05

2010-04

2010-03

2010-02

2010-01

Crude Oil Prices and Liquidity, the BRIC and G3 Countries, Ronald A Ratti and Joaquin L Vespignani

Crude Oil Prices: China’s Influence Over 1996-2011, Ronald A Ratti and Joaquin L Vespignani

Exchange Rate Risk Exposure and the Value of European Firms, Fabio Parlapiano and Vitali Alexeev

Ranking Systemically Important Financial Institutions, Mardi Dungey, Matteo Luciani and David Veredas

Identification-Robust Inference for Endogeneity Parameters in Linear Structural Models, Firmin Doko Tchatoka and Jean-Marie Dufour

Specification Tests with Weak and Invalid Instruments, Firmin Doko Tchatoka

Liquidity and Crude Oil Prices: China’s Influence Over 1996-2011, Ronald A. Rattia and Joaquin L. Vespignani

On the Validity of Durbin-Wu-Hausman Tests for Assessing Partial Exogeneity Hypotheses with Possibly Weak Instruments, Firmin Doko Tchatoka

Endogenous Crisis Dating and Contagion Using Smooth Transition Structural GARCH, Mardi Dungey, George Milunovich, Susan Thorp and Minxian Yang

Testing for Partial Exogeneity with Weak Identification, Firmin Doko Tchatoka

On the Correspondence Between Data Revision and Trend-Cycle Decomposition, Mardi Dungey, Jan PAM Jacobs and Jian Tian

Systematic and Liquidity Risk in Subprime-Mortgage Backed Securities, Mardi Dungey, Gerald P. Dwyer and Thomas Flavin

A SVECM Model of the UK Economy and The Term Premium, Mardi Dungey and M. Tugrul Vehbi

Do Contact Matter in the Process of Getting a Job in Cameroon? Firmin Doko Tchatoka and Urbain Thierry Yogo

Subset Hypotheses Testing and Instrument Exclusion in the Linear IV Regression, Firmin Doko Tchatoka

First home Buyers’ Support Schemes in Australia - Results Spreadsheet, Mardi Dungey, Graeme Wells and Sam Thompson

First home Buyers’ Support Schemes in Australia, Mardi Dungey, Graeme Wells and Sam Thompson

Financial Crises in Asia: Concordance by Asset Market or Country?, Mardi Dungey, Jan P.A.M. Jacobs and Lestano

Innovation Contracts with Leakage Through Licensing, Shane B. Evans

Franchise Contracts with Ex Post Limited Liability, Shane B. Evans

Menus of Linear Contracts in Procurement with Type-Dependent Reservation Utility, Shane B. Evans

Decomposing the Price Effects on the Cost of Living for Australian Households, Paul Blacklow

Modelling the Time Between Trades in the After-Hours Electronic Equity Futures Market, Mardi Dungey, Nagaratnam Jeyasreedharan and Tuo Li

Cojumping: Evidence from the US Treasury Bond and Futures Markets, Mardi Dungey and Lyudmyla Hvozdyk

Assessing the Impact of Worker Compensation Premiums on Employment in Tasmania, Paul Blacklow Non-Linear Pricing with Homogeneous Customers and Limited Unbundling, Hugh Sibly

Detecting Contagion with Correlation: Volatility and Timing Matter, Mardi Dungey and Abdullah Yalama

From Trade-to-Trade in US Treasuries, Mardi Dungey, Olan Henry and Michael McKenzie

Copies of the above mentioned papers and a list of previous years' papers are available from our home site at http://www.utas.edu.au/economics-finance/research/ 